\title{
Improving Students' Speaking Competence Using Authentic Materials
}

\author{
Allamyrat Garajayev, Dewi Rochsantiningsih, Siswantoro \\ English Education Department \\ Teacher Training and Education Faculty \\ Sebelas Maret University of Surakarta
}

Email: alam74@mail.ru

\begin{abstract}
This study focused on the implementation of using authentic materials in improving the students' speaking competence in a bilingual boarding of high school in Central Java. The goals of this study are, (1) to describe whether the use authentic materials can improve the students' speaking competence in class, (2) to reveal the difficulties of using authentic materials in this research. I adopted Classroom Action Research (CAR) which requires four steps, namely planning, implementing, observing, and reflecting. The participants are 26 high school students. The methods of data collection are observation, diary, interview, photograph, pre-test, and post-test. In analyzing data I used (1) constant comparative technique by Burns (1999) (qualitative), (2) descriptive statistic technique (quantitative). After analyzing the data, I found out that the change in improvement of the students' speaking in class is seen clearly and all the responses from the students are positive. The average score of the students speaking skill increased from 63.46 to 79.80 .
\end{abstract}

Keywords: speaking competence, authentic materials, classroom action research

\section{INTRODUCTION}

Learning English is learning how to communicate it well both in oral and written. In Indonesia, English is taught from kindergarten and elementary school until university levels. So, it is undeniable that it represents "power, success and prestige" (Graddol 1997 in Zacharias, 2003: 65). In Indonesia, teaching English emphasizes on the students' ability of the four language skills that are listening, speaking, reading and writing. These four skills should be reinforced equally which link each other as a unity. The integration of the four skills is the only plausible approach within a communicative, interactive framework (Brown, 2001: 234).

Teaching English in SBBS, as teaching English in Senior High School in Indonesia, is also aimed at developing communicative competence in skills such as listening, speaking, reading, and writing. Hymes states that communicative competence is what a speaker needs to know in order to gain competence of communication in a speech community. In order to gain communicative competence, a student has to acquire not only knowledge but also ability of language use (Hymes in Kusumaningsih, 2013).

One of the manifestations of communicative competence is speaking. Speaking, as one of English skills taught in Senior High School, is important. It is a crucial part of teaching and learning English as it is one of abilities to carry out conversation. It is interactive process of constructing meaning that involves producing, receiving, and processing information (Wallace, 2004: IBE Journal).

Meanwhile, Chaney declares that "speaking is the process of building and sharing meaning through the use of verbal and non verbal symbols, in a variety of context" (Chaney in Paul, 2003: 138). The students should have the ability to speak 
English well in order that they can communicate with others and express themselves.

Unfortunately, the use of English is not so simple because the speaker should also master aspects of pronunciation, grammar, vocabulary, fluency and comprehension. In that case, a teacher needs to be creative in developing teaching learning process. He must create good atmosphere and comfortable situation for students to join speaking class actively. He ought to provoke the interest and involvement of the students in the subject of oral communication. In short, the teacher must give attention to such aspects of speaking as well as encourage the students' motivation (Tompkins, 2008).

However, it is the fact that the tenth grade students of SMAN SBBS face serious problem dealing with their own oral English. Their speaking competence is considered low as I noticed some indicators such as: (1) the students had difficulties in using grammar correctly. For example: "Our lesson is almost finish", "I haven't thing about that"; (2) the students could not pronounce the words correctly; (3) the students had problems in finding the appropriate words for certain situation, for example: "...how about if I bring you to Green Canyon..."; (4) the students spoke with lots of pauses and they translate their ideas directly from Indonesian, for example: "I think so .... so what time we ....ahm we will meet again?"

The students still encounter some problems in using their English for speaking because they do not have adequate practice time and guidance. It is unfortunate that many students still got very low speaking competence. Therefore, it is the teacher's task to teach speaking in such a way, so that the students can participate the lesson eagerly.

Speaking is "the process of building and sharing meaning through the use of verbal and non-verbal symbols, in a variety of contexts" (Chaney: 2003). It is interactive process of constructing meaning that involves producing, receiving, and processing information (Wallace, 2004).

Meanwhile, Chaney states that "speaking is the process of building and sharing meaning through the use of verbal and non verbal symbols, in a variety of context" (Chaney in Paul, 2003: 138). In learning speaking, the students should gain the ability to speak English well in order that they can communicate with others and express themselves. The pronunciation, grammar, or vocabulary should be concerned so that their utterances and ideas are understandable.

According to Oxford Advanced Dictionary, skill is (of person) having ability, power, authority, skill, knowledge etc (to do what is needed). Speaking competence refers to communicative competence. In the communicative model of language teaching, the teacher helps his students to develop their speaking competence by providing some practices that prepares students for real-life communication situations. $\mathrm{He}$ helps his students develop the ability to produce grammatically correct, logically connected sentences that are appropriate to specific contexts, and to do so using acceptable (that is, comprehensible) pronunciation (Kayi, 2006). So, speaking competence is the ability to express opinion, idea, thought and feelings in the form of understandable talking. Furthermore, the ability can be gained by practice.

Rodgers (1987:467) defines

authentic materials as 'appropriate' and 'quality' in terms of goals, objectives, learner needs and interest and 'natural' in terms of real life and meaningful communication. Harmer (1991), cited in Matsuta (n.d., para. 1) defines authentic texts as materials which are designed for native speakers; they are real text; designed not for language students, but for the speakers of the language. Authentic texts refer to texts that are not written for language teaching purposes. Authentic materials are significant since they increase students' motivation for learning, makes the learner be exposed to the 'real' language. The main advantages of 
using authentic materials are: a) they have a positive effect on learner motivation; b) they provide authentic cultural information; c) they provide exposure to real language; d) they relate more closely to learners ' needs; and e) they support a more creative approach to teaching.

Richards (2001:253) points out that alongside with these advantages, authentic materials often contain difficult language, unneeded vocabulary items and complex language structures, which cause a burden for the teacher in lower-level classes. Martinez (2002) mentions that authentic materials may be too culturally biased and too many structures are mixed, causing lower levels to have a hard time decoding the texts.

\section{RESEARCH METHODS}

The method I used in this paper is action research, which is known with many other names, including participatory research, collaborative inquiry, emancipatory research, action learning, and contextual action research, but all are variations on a theme. Put simply, action research is "learning by doing" - a group of people identify a problem, do something to resolve it, see how successful their efforts were, and if not satisfied, try again. While this is the essence of the approach, there are other key attributes of action research that differentiate it from common problemsolving activities that we all engage in every day.

Also, Kemmis and McTaggart (1988:5) support the idea above by defining action research as a form of collective selfreflective inquiry undertaken by participants in social situation in order to improve rationally and justice of their own social or educational practices, as well as their understanding of this practice and the situation in which the practices are carried out.

Action research is a method which emphasizes on action, with research as a fringe benefit. It is conducted to solve that the real problems. If the result of the action is not satisfied for the researcher, she or he may try the action research again and again. Action research can also be undertaken by organization or institutions guided by professional researchers, with the aim of improving their strategies, practices, and knowledge of the environments within which they practice and solving the problems.

This classroom action research was carried out at a boarding high school in 2014-2015 academic year. The classroom is at the second floor. The class is large, so it has enough places for managing every activity. The research is carried out in November 2014 - February 2015 by using authentic materials to improve students' speaking competence.

The data of this research are collected by using some techniques of qualitative and quantitative data collection. Qualitative data collection includes: interview, observation, diary, and document analyses. Photograph was also taken during the implementation of the research to provide more accurate data. I used the students` scores for speaking class as quantitative data. The data which are collected in the study consist of the information gained in pre-research, the process and the result of action research implementation. The whole application of the data collection used in this study is summarized in Table 1. Test technique is conducted by giving pre-test before the action began and post-test in the end of the each cycle. The tests are oral and focused on testing speaking skill. 
Table 1. Data Collection

\begin{tabular}{|c|c|c|c|}
\hline Steps of the study & Participants & Technique & Data \\
\hline Pre-Research & $\begin{array}{l}\text { Researcher } \\
\text { Students }\end{array}$ & $\begin{array}{l}\text { Observation } \\
\text { Interview } \\
\text { Test }\end{array}$ & $\begin{array}{l}\text { Observation report } \\
\text { Transcript of the interview } \\
\text { Transcript of the pre-test }\end{array}$ \\
\hline Implementation & Researcher & $\begin{array}{l}\text { Observation } \\
\text { Photograph } \\
\text { Document analyses } \\
\text { Test }\end{array}$ & $\begin{array}{l}\text { Field notes } \\
\text { Photographs of teacing- } \\
\text { learning process } \\
\text { Lesson Plan } \\
\text { Students`Speaking Scores }\end{array}$ \\
\hline Result discussion & $\begin{array}{l}\text { Researcher } \\
\text { Students }\end{array}$ & Post-test & Transcript of post-test \\
\hline
\end{tabular}

In analyzing the qualitative data, I use constant comparative technique. The data are analyzed to get conclusion of each cycle. I use descriptive statistic technique to analyze the quantitative data.

\section{RESEARCH FINDINGS AND DISCUSSIONS}

This research is a classroom action research on the use of authentic materials to improve the students' speaking competences. The purposes are to describe whether the use of authentic materials can improve the students' speaking competence in class X SMA Negeri Sragen Bilingual Boarding School and to reveal the difficulties of using authentic materials in class X SMA Negeri Sragen Bilingual Boarding School. The data are obtained by interviewing, observating, giving questionnaire, testing and taking photograph.

The research is conducted in class X$B$ of a Boarding Senior High School. Before doing the research, I have done some activities called pre-research. The activities are interviewing, observing and conducting pre-test. In the pre-research, I use interview, observation and pre-test.

I find most of the students do not have interest in learning English especially in speaking. It is proved that most of them get bored in following the teaching and learning process. Most of them chose talking with their friends rather than paying attention to the teachers' explanation. It is because the teacher does not use the method that is able to make the students to be more active and interested in following the teaching and learning process. The situation before the research could be seen in table 2 .

Table 2. Situation before the Research

\begin{tabular}{|c|c|c|}
\hline Prob & em Indicators of Speaking & Situation Before The Research \\
\hline \multicolumn{3}{|c|}{ a. The students' problem } \\
\hline & $\begin{array}{l}\text { The students have difficulties in } \\
\text { using grammar correctly }\end{array}$ & $\begin{array}{l}\text { 1) The students produces many wrong } \\
\text { sentences in their speech }\end{array}$ \\
\hline & $\begin{array}{l}\text { The students can not pronounce the } \\
\text { words correctly }\end{array}$ & $\begin{array}{l}\text { 2) The students pronounce some vocabulary } \\
\text { incorrectly }\end{array}$ \\
\hline & $\begin{array}{l}\text { The students have problems in } \\
\text { finding the appropriate words for } \\
\text { certain situation }\end{array}$ & $\begin{array}{l}\text { 3) The students repeate the same words in } \\
\text { many expressions }\end{array}$ \\
\hline & $\begin{array}{l}\text { The students speak with a lot of } \\
\text { pauses and they translate their ideas } \\
\text { directly from Indonesian }\end{array}$ & $\begin{array}{l}\text { 4) The students produce many stops and fillers } \\
\text { during their speech }\end{array}$ \\
\hline \multicolumn{3}{|c|}{ b. The students' Behavior/Classroom Situation } \\
\hline & $\begin{array}{l}\text { The students do not give responses to } \\
\text { the teacher question }\end{array}$ & $\begin{array}{l}\text { 1) The students are afraid of or ashamed of to } \\
\text { answering the teacher's question. }\end{array}$ \\
\hline & $\begin{array}{l}\text { The students have less interest in } \\
\text { learning English }\end{array}$ & $\begin{array}{l}\text { 2) Most of the students choose talking with } \\
\text { their friends rather paying attention to the } \\
\text { teacher's explanation. }\end{array}$ \\
\hline
\end{tabular}


From the pre research, I get the data from interviewing, observating and pre test. From the data, I design and prepare the research plans such as the interview sheet, observation sheet, questionnaire sheet, etc. There are two cycles in the research. Cycle 1 consist of three meetings and cycle 2 consisted of two meetings. While the action is implementing, I also observe the teaching and learning process. Then, the reflection is conducted in the end of each cycle in order to know about the students' responses and improve the teaching and learning before conducting the next cylce.

During two cycles and five meetings I conduct several activities that use authentic materials to improve students' speaking competence. I note the improvement during the process. There are some kinds of authentic materials such as news video, broadcast and song.

The research on the use of authentic materials to improve the students' speaking competences at tenth grades students of Senior High School in the academic year of 2014/2015 prove the purposes namely identifying the students' improvement in the speaking competences and identifying the difficulties of using media (authenti materials) in the research at tenth grades students of SMA N Sragen Bilingual Boarding School (SBBS). The class achievement is summarized in Table 3.

Table 3. Improvement of Class Achievement

\begin{tabular}{lll}
\hline Test & Mean Score & Improvement \\
\hline Pre test & 63.46 & \\
Test 1 & 70.91 & 7.45 \\
Test 2 & 79.80 & 8.89 \\
\hline
\end{tabular}

There are also the detail scores of getting the mean of each test conducted. The indicator score improvement appear in Table 4.

Table 4. Summary of Indicator Score Improvement

\begin{tabular}{lcccc}
\hline & Fluency & Grammar & Pronunciation & Vocabulary \\
\hline Pre test & 63.4 & 65.3 & 60.5 & 64.4 \\
Test 1 & 71.1 & 66.3 & 71.1 & 75 \\
Improvement 1 & 7.7 & 1 & 10.6 & 10.6 \\
\hline Test 2 & 79.8 & 79.8 & 79.8 & 79.8 \\
Improvement 2 & 8.7 & 13.5 & 8.7 & 4.8 \\
\hline Total Improvement & 16.4 & 14.5 & 19.3 & 15.4 \\
\hline
\end{tabular}

After implementing two cycle, I find some difficulties in using authentic materials as a media that could help to improve the students' speaking competences at tenth grades students of SMA N Sragen Bilingual Boarding School. Those difficulties are as follows:

1) Because some of the authentic materials are done by watching video, it should be supported with facilities from the school. If the school facilities do not support, the teacher should be more creative to give the best solution.

2) The students feel enjoy and are motivated to follow the learning using authentic material. They usually wait for the new materials based on authentic materials. It 
cause the teacher to be more creative to design or look for the authentic materials.

3) Because of the students' enthusiam in watching the video related to the authentic materials, they cause the class situation to be a little noisy. The teacher has to manage the classroom situation in order that the teaching and learning process could be running well.

The students' speaking competences could be improved by implementing authentic materials as the teaching media. The indicators of speaking improvement such as grammar, vocabulary, content, fluency and pronunciation have improved better. Many activities are conducted in order to motivate the students to be more active in involving in the teaching and learning process. Those activities are watching video, a group discussion, a pair discussion, making dialogue transcript, doing presentation and debating. Those activities were not only giving good effect from the students but also changing the class situation became more interesting, helpful and enjoyable.

Moreover, the authentic materials were not only able to improve the students' speaking competences but also the students' attitude. From discussion, the students could share their opinion and learn to accept any opinions from other friends. Even from working in group or in pairs, the students could learn working together involved in the making the task. Through debate, the students could learn to pay attention toward other explanation. The activities in implementing this research could change the students' behavior better.

Since the teaching media was innovative, the students were very enthusiastic in following all of activities in the teaching and learning process. The authentic materials which consist of videos or songs had successed in facilitating the students in learning English especially speaking competences. Besides, the authentic materials could improve the students' speaking competence, it also improves the students' attitudes. From the reasons above, it could be stated that authentic materials is effective and suggest to be implemented to teach English subject especially speaking skill.

Besides authentic materials give many advantages to teaching English especially speaking skill. They also have some weaknesses. Those weaknesses cause the researcher to get difficulties in implementing authentic materials. During implementation of the research, I find several difficulties in using authentic materials as the teaching media. The difficulties related to three points, are about the school facilities, new innovation of authentic materials and classroom situation.

The first point is about the school facilities. The examples of authentic materials are: a) newspapers: local papers will give more of a flavor of everyday life in towns; b) video: a number of published ELT video tapes are a good visual source of cultural information. This research tend to use the video as a media in the implementing the research. Therefore, the implemention of teaching English using authentic materials especially in the use of video should support by the school facilities. If the school facilities do not support well, the teacher should be more creative to give the best solution. 
In addition, authentic materials could motivate the students in learning English more. They are very enthusiastic in the teaching and learning process. Unfortunately, most of the teacher could use this condition as well as possible. Some of them do not have time to provide the newest materials. It could cause the studnets' enthusiasm would decrease. The students are bored easily with the monotonous materials. Therefore, the teacher should be more creative and innovative in designing or looking for variety of materials related to authentic materials.

Nevertheless, the students' enthusiasm in learning English also could cause the class situation became noisy. It is the most important problem. The teaching media motivate the students to be active and enthuasiastic in the class. That is like the teacher who expects before. So the teacher should give the best solution for this problem in order to make the students stay enthusiastic but they do not cause the class situaion to be noisy even in disorder situation. The teacher has to manage the classroom situation to be attractive and conducive.

\section{CONCLUSIONS AND SUGGESTIONS}

After the research has been completely conducted, the data is processed. Based on the result of the research, I make several conclusions as presented below:

The implementation of teaching speaking English using authentic materials could be done in various materials for example song and video.

Since the use of authentic materials is implemented in the teaching and learning process, the students' responses are very good. The students' interest to the learning English especially speaking English after implementing the teaching and learning by using authentic materials shows positive responses. Their interest in learning English is improved. They give a good response such as being active in the class, have good scores and enthuasiasm in learning speaking English. The students' responses also could be seen in the result of questionnaire shown in Table 5.

Table 5. The Result of Questionnaire

\begin{tabular}{lll}
\hline $\begin{array}{l}\text { Item of } \\
\text { Questions }\end{array}$ & Yes & No \\
\hline 1 & $24=92.30 \%$ & $2=7.69 \%$ \\
2 & $23=33.33 \%$ & $3=11.53 \%$ \\
3 & $24=92.30 \%$ & $2=7.69 \%$ \\
4 & $20=76.92 \%$ & $6=23.07 \%$ \\
5 & $12=46.15 \%$ & $14=53.84 \%$ \\
6 & $19=73.07 \%$ & $7=26.92 \%$ \\
7 & $11=42.30 \%$ & $15=57.69 \%$ \\
8 & $8=30.76 \%$ & $18=69.23 \%$ \\
9 & $10=38.46 \%$ & $16=61.53 \%$ \\
10 & $6=23.07 \%$ & $20=76.92 \%$ \\
11 & $11=42.30 \%$ & $15=57.69 \%$ \\
12 & $10=41.66 \%$ & $14=58.33 \%$ \\
\hline
\end{tabular}


Considering the result of the research, I conclude that there is an improvement in the students' speaking competences after the treatments. It is proved by the comparison between the students speaking score in the pre-test and post-test. The mean score of post test 1 is 70.91. Whereas the mean score of pre test is 63.46. The mean score of post test 1 is higher than the mean score of pre test. It increases 7.45. Then the mean score of post test 2 is 79.80 . Whereas the mean score of post test is 70.91 . The mean score of post test 2 is higher than the mean score of post test 1 . It increases 8.89 . It proves that the use of authentic materials could improve the students' speaking competence

Besides authentic materials give many advantages to teaching English especially speaking skill, they also have some weaknesses. Those weaknesses cause the researcher to get difficulties in implementing authentic materials. During implementation of the research, I find several difficulties in using authentic materials as the teaching media. The difficulties are related to three points, those are about the school facilities, new innovation of authentic materials and classroom situation.

After analyzing the data presented in chapter IV, I would give some suggestions related to this research closely related to English teaching and learning process. I expect that these following suggestions will be useful for many sides especially for the teacher, other researcher, and for the students.

a. For the teachers

This study can contribute to the development of teaching media for speaking and provide some practical benefits about how to use authentic materials to improve the students' speaking competence. By gaining various experiences and methods in the teaching English, the teacher will be more confident in facilitating the teaching and learning process.

b. For the other researchers

Other researchers can use this study to develop the students' speaking competence. From this study, it is expected it can give more information as a consideration for the other researchers in writing their thesis.

c. For the students

Most of students get difficulties in learning English especially in speaking. So from this study, it is expected that the students can learn speaking easily and make the students more confident in answering the teachers' question and they can get scores above passing grades. Besides, they not only can improve their speaking competence but also their attitudes in following the speaking class.

\section{BIBLIOGRAPHY}

Brown, H. Douglas. (2001). Teaching by Principles. San Francisco: Longman, San Francisco State University.

Burns, A. (1999). Collaborative action research for English language teachers. Cambridge: Cambridge university press.

Harmer, Jeremy. 1984 How to Teach English In Introduction to the Practise of English Language Teaching. London: Longman

Kayi, Hayriye. 2006. Teaching Speaking: Activities to Promote Speaking in a Second Language. Nevada: University of Nevada. Retrieved from http://tesl.org/Articles/KayiTeachingSpeaking.html.

Kemmis, Stephen \& McTaggart, Robin (eds.). (1988). The action research 
planner. Victoria: Deakin University Press.

Kusumaningsih, 2013. Teaching Reading Comprehension in ESL/EFL Learners.The Reading Matrix. 5(2). Retrieved from http:www.thereadingmatric.com.

Paul, David. 2003. Teaching English to Children in ASIA. New York: Cambridge University.

Richards, Jack C., Theodore S. Rodgers. 1986. Approaches and Methods in Language Teaching. A Description and Analysis. Cambridge: Cambridge University Press.

Tompkins, Patricia K. 2008. Role Playing/Simulations. The Internet TESL Journal. 4(8). Retrieved from http://iteslj.org/Techniques/Tompkin sRolePlaying.html

Wallace. Teaching Second Language Speaking. From an Interactive Perspective. IBE Journal. Retrieved from http:www.nadasisland.com/ reading. 